3. Марінушкіна О. Є. Порадник практичного психолога / О. Є. Марінушкіна, Ю. О. Замазій. - Х.: Вид. група «Основа», 2007. C. $45-50$.

DOI https://doi.org/10.30525/978-9934-26-114-5-3

\title{
ЗДІБНОСТІ ТА ОБДАРОВАНІСТЬ ЯК ОДИН 3 ЧИННИКІВ ОРГАНІЗАЦІЇ ОСОБИСТОСТІ
}

\author{
Юсіфова А. А. \\ практичний психолог \\ Комунальний заклад «Херсонський фаховий коледж \\ музичного мистецтвв » \\ Херсонської обласної ради \\ м. Херсон, Украӥна
}

Провідні світові держави, піклуючись про своє майбутнє, відрізняються постійною увагою до формування культурного потенціалу нації в умовах підвищення інтересу до феномену здібностей та обдарованості (про що свідчить розгортання різноманітних програм щодо розкриття та реалізації можливостей особистості). Одним із завдань, що стоїть перед Україною, яка порівняно нещодавно заявила про себе як про самостійну самобутню державу, є продовження формування культурної еліти у найкращих національних традиціях.

Аналіз наукової літератури свідчить про те, що за даними історичного та порівняльного аналізу, проведеного О.С. Антоновою [1] та О.В. Бобир [2; 3], умовно розвиток психології здібностей та обдарованості можна розділити на три етапи. Перший етап датується 2-ю пол. XIX ст. - серед. XX ст., хоча хронологічний розподіл у даному випадку є доволі умовним. Йому передує накопичення певного досвіду, зацікавленості питаннями здібностей такими філософами, як Августин, Аристотель, К. Гален, Геракліт, Гіппократ, Емпедокл, А. Ібн Аль-Хайсам (або Альгазена), А. Ібн Сіна (або Авіценна), Парменід, Платон, Плотін, Фома Аквінський. Здібності як психічні явища розглядали Ф. Бекон, Ф. Бенеке, Ш. Бонне, Х. Вольф, І.Ф. Гербарт, Т. Гоббс, Я.А. Коменський, Г. Лейбніц, Дж. Локк, Т. Рід, Б. Спіноза, $\mathrm{X}$. Уарте та ін. Феномен здібностей як психічних функцій висвітлений у працях Ф.І. Галля, К.А. Гельвеція, Д. Дідро, П.Ж. Кабаніса, Е.Б. де Кондильяка, І. Прохазки та ін. [11]. 
Перший етап пов'язаний $з$ ототожненням обдарованості 3 інтелектом, або обумовлений мірою консервативності (за Дж. Рензуллі [7, с. 451]. Цьому етапу притаманне вивчення інтелекту відповідно до поглядів науковців, а також визначенню, пошуку або спростуваню генерального G-фактора, що, у свою чергу, перегукуючись із проблемами вітчизняної психології, порушувало питання про співвідношення між загальними та спеціальними здібностями. Серед перших емпіричних досліджень обдарованості зазвичай згадують А. Бена, В. Вундта, Е. Клапареда, Г.І. Розсолимо, В. Штерна та ін. Своєрідною точкою відліку психології здібностей вважаються «дослідження розуму» Ф. Гальтоном (1883) [5, с. 7-9; 4, с. 13-14]. На цьому етапі розвитку виникли факторні моделі Т. Келлі (1928), Р.Ф. Кеттелла (1971), Ч. Спірмена (1904), Л. Терстоуна (1938); ієрархічні моделі С. Барта (1949), Д. Векслера (1958), Ф. Вернона (1950), де «поверх» ієрархії визначався мірою узагальнення фактора; монометрична позафакторна модель інтелекту Г. Айзенка (1979) тощо.

Другий етап психології здібностей, початок якого пов'язаний 3 концепцією творчого інтелекту Дж. Гілфорда (1969), знаменується виходом за межі тлумачення здібностей та обдарованості лише тільки характеристиками інтелекту. Цей етап характеризується суперечливим ставленням до творчих здібностей (правомірність існування яких відстоювали Дж. Гілфорд, Г. Грубер, Я.А. Пономарьов, К. Тейлор та ін., заперечували Д.Б. Богоявленська, А. Маслоу, О.М. Матюшкін, А. Олох, А. Танненбаум та ін., і намагалися узгодити різні точки зору Г. Айзенк, Д. Векслер, Р. Стернберг, Л. Термен, Р. Уайсберг та ін. [5, с. 168-169]), унікальним ставленням до художньої творчості А.А. Мелік-Пашаєвим [8, с. 40-44]); розглядом здібностей як багатоаспектного явища (теорії Х. Гарднера (1983), Дж. Рензуллі (1978), Р. Стернберга (1984) [7, с. 451]); спробою пояснити відмінності результативності інтелекту позаінтелектуальними чинниками $[5$, с. $40-52]$; розглядом психології здібностей у межах так званих теорій обдарованості (трикільцева модель обдарованості Дж. Рензуллі, мультифакторна модель Ф. Монкса (1996), п’ятифакторна модель обдарованості А. Танненбаума (1983), «мюнхенська модель» К. Хеллера (1992) та ін. ).

Третій етап у розвитку психології здібностей характеризується аналітичним інтегративним підходом до вивчення здібностей та обдарованості, що відповідає системно-структурному принципу (перехідною до цього етапу $є$ концепція В.Д. Шадрікова (1983), який застосував для аналізу здібностей та обдарованості теорію функціональних систем П.К. Анохіна [15]; системний розгляд здібностей та обдарованості у працях Д.Б. Богоявленської [2]; концепції О.I. 
Кульчицької, В.О. Моляко, О.Л. Музики, В.М. Онацького та ін. [1]). Поступово складається уявлення про здібності як про динамічне системне утворення, що має вкрай індивідуалізований прояви. Найчастіше як складові обдарованості згадуються здібності високого рівня розвитку, креативність і мотивація у різних іiі інтерпретаціях (наприклад, спрямованість). Узагальнення поглядів різних вчених приводить до розуміння здібностей та обдарованості як до системи, що охоплює такі компоненти: біофізіологічні, анатомо-фізіологічні особливості (задатки); сенсорно-перцептивні блоки, що характеризуються підвищеною чутливістю; інтелектуальні здібності, що дозволяють оцінювати нові ситуації і розв'язувати нові проблеми; емоційно-вольові структури, що передбачають тривалі домінантні орієнтації, їх штучна підтримка; високий рівень продукування нових образів, фантазія, уява тощо [1, с. 271].

Принципу системності відповідають розуміння здібностей С.Л. Рубінштейном і Б.М. Тепловим, які розуміли їх як «складне синтетичне утворення, побудоване за ієрархічності та субординаційними принципами, що включає в себе цілий ряд даних, без яких людина не була б здатна до будь-якої конкретної діяльності, та властивостей, які виробляються лише у процесі певним чином організованої діяльності» [13, с. 537]; «кожна здібність змінюється, набуває якісно нового характеру залежно від наявності і міри розвитку інших здібностей» [14, с. 17]. В.Д. Шадріков для визначення категорії здібностей використовує поняття психічної функціональної системи, процес функціонування якої (психічний процес) забезпечує досягнення певного корисного результату [15, с. 38-39].

Грунтуючись на поглядах С.Л. Рубінштейна, К.К. Платонова, можна стверджувати, що елементами цієї системи є психічні процеси: «жодна здібність не $\epsilon$ актуальною... здібністю, доки вона органічно не увібрала в себе систему відповідних суспільно вироблених операцій; але ядро здібності - це не засвоєна, не автоматизована операція, А ті психічні процеси, засобом яких ці операції, їх функціонування регулюється, якість цих процесів» [13, с. 5-9]; будь-який психічний процес, який проявляється в певній та має значення для успішності її виконання, $€$ здібністю [11, с. 87; 10, с. 99-100].

Актуальним $є$ питання про співвідношення загальних та спеціальних здібностей: «Лише єдність загальних i спеціальних властивостей, узятих у їх взаємопроникненні, окреслює істинний обрис обдарованості людини» [13, с. 541]. Загальноприйнятими є позиції Б.Г. Ананьєва, А.В. Петровського, С.Л. Рубінштейна, Б.М. Теплова, які розглядають розвиток спеціальних здібностей залежно від загальних. 18 
А.Г. Ковальов і В.М. Мясищєв зауважують, що «...спеціальні здібності як властивості мозкової системи виступають на фоні загальної обдарованості...», і «...можуть виявлятися у декількох системах» [6, с. 266], та у якості прикладу згадують наукові і музичні здібності О.П. Бородіна, здібності до поезії, живопису та літератури Т.Г. Шевченка та Е.Т. Гофмана.

Традиційно здібності поділяють на елементарні і складні. До складу останніх входять елементарні (як основні форми психічного відображення), що являє собою своєрідний комплекс, пов'язаний із певною діяльністю [12, с. 153].

Передумовою розвитку здібностей вважаються задатки, тобто природжені анатомо-фізіологічні особливості індивідууму, що $\epsilon$ підгрунтям для розвитку здібностей [тепл233]; або «природні можливості для розвитку здібностей», що представлені у вигляді «сукупності індивідуально-психологічних особливостей» [1, с. 84] як умови виконання успішної діяльності; або джерела формування різних здібностей [16, с. 128-129].

Поряд із здібностями нерідко згадують такі поняття, як обдарованість, талант, геніальність, розглядаючи їх як своєрідні рівні розвитку здібностей. Обдарованість являє собою системну якість психіки, «що розвивається протягом життя, яка надає можливість досягнення людиною більш високих (незвичних, виняткових) результатів в одному або декількох видах діяльності порівняно 3 іншими людьми» $[9$, с. 5].

Отже, історичний розвиток загальнопсихологічної теорії здібностей характеризується тенденціями від аналітичного розгляду здібностей до ï представлення як складної ієрархічно узгодженої системи із взаємозв'язками з особистісними якостями. Взагалі сучасне розуміння здібностей та обдарованості спрямоване на подолання певної ізольованості від особистісних характеристик. Таким чином, здібності можна розглядати як «системне утворення особистості» [1, с. 261], що $є$ своєрідним організатором, чинником, що впливає на ієрархію взаємозв'язків складових структури особистості.

\section{Література:}

1. Антонова О.Є. Обдарованість: досвід історичного та порівняльного аналізу. Житомир, 2005. 456 с.

2. Бобир О.В. Особистісні характеристики юнацтва 3 різними формами обдарованості: дис. ... канд. психол. наук: 19.00.07. Дніпропетровськ, 2005. 198 арк. 
3. Бобир О.В. Особистісні характеристики юнацтва 3 різними формами обдарованості: автореф. дис. ... канд. психол. наук: 19.00.07. Дніпропетровськ, 2005. 20 с.

4. Бурлачук Л.Ф. Психодиагностика: учебн. для студ. высш. учеб. заведений. СПб: Питер, 2006. 351 с.

5. Дружинин В.Н. Психология общих способностей. СПб: Питер, 2002. $368 \mathrm{c}$.

6. Ковалёв А.Г., Мясищев В.Н. Психические особенности человека. Т. 2: Способности. Ленинград: Изд-во Ленингр. ун-та, 1960. 304 с.

7. Корольов Д.К. Шляхи визначення взаємозв'язку когнітивних та особистісних чинників обдарованості. Наукові записки Інституту психології ім. Г.С. Костюка АПН Украӥни. Київ: Міленіум, 2006. Вип. 28. С. $450-469$.

8. Мелик-Пашаев А.Ш. Мир художника. Москва: ПрогрессТрадиция, 2000. $271 \mathrm{c}$.

9. Одаренность. Рабочая концепция / Д.Б. Богоявленская, A.В. Брушлинский, М.А. Холодная, В.Д. Шадриков и др. URL: http://www.soudo.ru/omcso/Koncepciaodarennosti.doc/.

10. Петрушин В.И. Музыкальная психология. Москва: Гаудеамус, 2009. $400 \mathrm{c}$.

11. Платонов К.К. Проблемы способностей. Москва: Наука, $1972.310 \mathrm{c}$.

12. Платонов К.К. Структура и развитие личности. Москва: Наука, 1986. $252 \mathrm{c}$.

13. Рубинштейн С.Л. Основы общей психологии. СПб: Питер, $2010.720 \mathrm{c}$.

14. Теплов Б.М. Способности и одаренность // Избранные труды. Т. 1. Москва: Педагогика, 1985. С. 15-41.

15. Шадриков В.Д. О содержании понятий «способности» и «одаренности». Психологический журнал. 1983. Т. 4. N-5. С. 38-46.

16. Шапарь В.Б. Словарь практического психолога. Москва: АСТ; Харьков: Торсинг, 2004. 734 с. 